\title{
The effect of preliminary chilling of broccoli transplants on some antioxidative parameters
}

\author{
Olga Dlugosz-Grochowska ${ }^{1}$, Maria Leja ${ }^{1 *}$, Aneta Grabowska ${ }^{2}$,Edward Kunicki ${ }^{2}$
}

\author{
${ }^{1}$ Department of Botany and Plant Physiology \\ ${ }^{2}$ Department of Vegetable and Medicinal Plants \\ University of Agriculture in Krakow \\ 29 Listopada 54, 31-425 Kraków, Poland
}

\begin{abstract}
The aim of this study was to introduce older transplants of broccoli into field conditions to shorten their growing period and to obtain a crop with a high nutritive value. The additional storage of relatively old (four- and eightweek-old) transplants in a cold chamber before planting in the field shortens the growing period; however, it can influence the chemical composition of the leaves and heads. According to earlier research, the preliminary chilling of transplants affected the high yielding of broccoli; a determination of the quality of plants, including select health-promoting properties, was necessary for their full characteristics.

In the present work, the four- and eight-week-old broccoli transplants were kept at $2{ }^{\circ} \mathrm{C}$ either for one or two weeks before planting in the field. Catalase (CAT) and peroxidase (POD) activity as well and the accumulation of phenolic compounds were determined in the leaves of the transplants before and after chilling. The same parameters were detected in the leaves and heads of broccoli at harvest time. The effect of low temperature treatment on CAT activity was observed only at the stage of transplants; however, the increased activity of POD stimulated by chilling was maintained during the growing period until the harvest. The reaction of the plants to low temperatures can be connected with their mechanism against stress conditions and seems to vary in the case of those antioxidative enzymes. The effect of chilling on the accumulation of phenolics (total, cinnamic acid derivatives, flavonols) was noted only in transplants and was not evident during the harvest.

The differences observed between the individual seasons of the experiment, both in enzyme activity and synthesis of phenolics, were most likely caused by the differing climatic conditions.
\end{abstract}

Key words: broccoli, Brassica oleracea var. italica, chilling, catalase, peroxidase, phenolics

\section{INTRODUCTION}

Disorders of redox processes occurring in plant tissues can lead to excessive formation and accumulation of free radicals, particularly active oxygen species (AOS) that can cause serious damage of essential metabolic constituents (Bartosz 2006). They are involved in the process of cell aging and contribute to the development of cardiovascular diseases, cancer and many others (Bartosz 2006, Grajek 2007). To effectively reduce the negative impact of free radicals, it is necessary to provide the body with adequate amounts of antioxidants, present mainly in fruits and vegetables.

Brassicaceae vegetables are widely known for their health-promoting properties (Singh et al. 2010). Due to the high amount of nutrients, 
Table 1. Monthly average air temperatures and total rainfall recorded at the Meteorological Station in Krakow (source: Polish Central Statistical Office, http://www.stat.gov.pl/gus)

\begin{tabular}{|c|c|c|c|c|c|c|c|c|}
\hline \multirow{2}{*}{ Year } & \multicolumn{4}{|c|}{$\begin{array}{l}\text { Average temperature } \\
\left({ }^{\circ} \mathrm{C}\right)\end{array}$} & \multicolumn{4}{|c|}{$\begin{array}{l}\text { Rainfall } \\
(\mathrm{mm})\end{array}$} \\
\hline & Jun & Jul & Aug & Sep & Jun & Jul & Aug & Sep \\
\hline 2008 & 18.4 & 18.7 & 18.2 & 12.6 & 27 & 143 & 42 & 97 \\
\hline 2009 & 16.0 & 19.9 & 18.6 & 15.2 & 121 & 83 & 53 & 35 \\
\hline 2010 & 17.3 & 20.4 & 18.3 & 12.0 & 131 & 105 & 163 & 82 \\
\hline
\end{tabular}

vitamins, antioxidants, and other specific substances beneficial to health (e.g. sulforaphane), broccoli is becoming a particularly valuable vegetable (Jeffrey and Araya 2009). According to many studies, the bioactive substances in broccoli can neutralise some carcinogens and even slow down cancer cell proliferation (Borowski et al. 2008).

The primary cell protection system against AOS is mainly due to antioxidant enzymes: superoxide dismutase (SOD), catalase (CAT) and peroxidase (POD). SOD catalyses the disproportionation of superoxide anion into hydrogen peroxide. Both CAT and POD are responsible for the removal of hydrogen peroxide, but peroxidase requires reduced substrate (e.g. ascorbic acid, guaiacol) to the reaction (Bartosz 2006, Sharma et al. 2011). The second group of antioxidants are low-molecular compounds, which are divided into hydrophobic antioxidants (e.g. carotenoids, tocopherols) and hydrophilic antioxidants (e.g. glutathione, ascorbate, phenolic compounds). Vegetables of the Brassicaceae family are rich in phenolic substances, especially cinnamic acid derivatives and flavonols (Podsędek 2007). Their high antioxidant activity is associated with their molecular structure (Bartosz 2006). Plant phenolics that possess one or more 'acidic' hydroxyl groups are characterised as aromatic compounds. The construction of the phenolic molecule can be relatively simple, (e.g. salicylic acid), as well as very complex (such as suberin and lignin) (Grace 2005). In recent years, research on the participation of phenols in essential physiological functions associated with acclimation to stressful environments, defence against pathogens, and general protection against oxidative stress has been very common (Shirley 1996).

The aim of this study was to determine the effect of transplant chilling on the activity of CAT, POD, and also the synthesis and accumulation of phenolic compounds in broccoli leaf tissues at the time of planting and in leaves and florets at the time of harvest.

\section{MATERIAL AND METHODS}

\section{Plant material}

The experiment was carried out in three growing cycles in the years 2008-2010. The plant material was broccoli cultivar 'Monaco' $\mathrm{F}_{1}$, grown in accordance with recommendations for the broccoli crop (Kunicki 1998). Transplants of broccoli were produced in the greenhouse. Four-week-old (sowing at the end of May) and eight-week-old transplants (sowing at the end of April) were kept in a dark cold chamber at $2{ }^{\circ} \mathrm{C}$ for one or two weeks before planting in the field on the permanent site. Transplants were planted at the end of June and July. Broccoli heads were harvested from 20 August to 14 September. After storage in a cold chamber, the four- and eightweek-old transplants were actually $5 / 6$ or $9 / 10$ weeks old at the moment of planting, respectively; however, the low temperature treatment in darkness effectively stopped their growth. The authors decided to describe their age as four- and eightweek-old.

Ten leaves of transplants were taken for analysis before ( 0 weeks of chilling) and after low temperature treatment ( 1 and 2 weeks of chilling). The mean sample of broccoli plants grown in the field consisted of five heads and 10 leaves randomly taken from each treatment.

The meteorological conditions that occurred during each growing period are shown in Table 1.

\section{Catalase}

The activity of enzymes was determined in fresh tissue at the day of plant collection using spectrophotometric methods with the use of a HITACHI U-2900 UV-VIS. The analysis of CAT activity was carried out according to the method described by Bartosz (2006). $2.5 \mathrm{~g}$ of chopped plant material was homogenised in ice-cold conditions with $20 \mathrm{~cm}^{3}$ of phosphate buffer at a concentration of $50 \mathrm{mmol} \mathrm{dm}^{-3}$ and $\mathrm{pH}$ 7.0. The sample was centrifuged at $4^{\circ} \mathrm{C}$ for 15 minutes at $2,700 \mathrm{~g}$. The obtained extract $\left(0.2 \mathrm{~cm}^{3}\right)$ was mixed with $1.8 \mathrm{~cm}^{3}$ of phosphate buffer and $1 \mathrm{~cm}^{3}$ of 
a $\mathrm{H}_{2} \mathrm{O}_{2}$ solution $\left(54 \mathrm{mmol} \mathrm{dm}^{-3}\right)$ in phosphate buffer. The absorbance of $\mathrm{H}_{2} \mathrm{O}_{2}$ decomposed by CAT was measured at a wavelength of $240 \mathrm{~nm}$ in one-minute intervals for four minutes at room temperature. As the unit of CAT activity, we assumed the amount of enzyme that decomposed $1 \mu \mathrm{mol} \mathrm{H}_{2} \mathrm{O}_{2}$ in one minute, causing a decrease of 0.0145 absorbance unit in one minute.

\section{Peroxidase}

POD activity was determined by the procedure described by Lück (1962) using p-phenyldiamine as the enzyme substrate, which is oxidised by POD to phenazine. $2.5 \mathrm{~g}$ of chopped plant material was homogenised in ice-cold conditions with $20 \mathrm{~cm}^{3}$ of phosphate buffer $\left(67 \mathrm{mmol} \mathrm{dm}^{-3}, \mathrm{pH}\right.$ 6.2). The sample was centrifuged at $4^{\circ} \mathrm{C}$ for 15 minutes at $2,700 \mathrm{~g}$. The obtained extract $\left(1 \mathrm{~cm}^{3}\right)$ was mixed with $1 \mathrm{~cm}^{3}$ of phosphate buffer, $0.1 \mathrm{~cm}^{3}$ of $1 \%$ solution of p-phenyldiamine and $0.1 \mathrm{~cm}^{3}$ of $0.1 \%$ $\mathrm{H}_{2} \mathrm{O}_{2}$. The absorbance of a coloured reaction product at a wavelength of $485 \mathrm{~nm}$ was measured. One unit of POD activity corresponds to an absorbance increase of 0.1 .

\section{Phenolic substances}

Samples for phenolic determination were frozen and kept at $-18^{\circ} \mathrm{C}$ until analysed. The content of total phenols, cinnamic acid derivatives and flavonols was measured using the spectrophotometric method according to Fukumoto and Mazza (2000). $2.5 \mathrm{~g}$ of chopped plant material was homogenized with $10 \mathrm{~cm}^{3}$ of $80 \%$ methanol and centrifuged at $4{ }^{\circ} \mathrm{C}$ for 15 minutes at 2,700 g. The sample consisted of $0.25 \mathrm{~cm}^{3}$ of obtained extract, $0.25 \mathrm{~cm}^{3}$ of $0.1 \%$ solution of $\mathrm{HCl}$ within $96 \%$ ethanol and $4.5 \mathrm{~cm}^{3}$ of $2 \% \mathrm{HCl}$. Absorbance was measured after 15 minutes at a wavelength of $280 \mathrm{~nm}, 320 \mathrm{~nm}$ and $360 \mathrm{~nm}$. The content of total phenols, cinnamic acid derivatives and flavonols was calculated with the use of calibration curves made for chlorogenic acid, caffeic acid and quercetin.

Determinations were made in three replications and were subjected to statistical analysis using Fisher's LSD test at the significance level of $\mathrm{p}=$ 0.05 . Results obtained for the leaves and heads in each growing season were separately statistically verified.

\section{RESULTS}

According to Table 1, thermic conditions were approximately similar in each year; however, differences in rainfall were observed.

\section{Catalase (CAT)}

CAT activity in broccoli transplants was affected by their chilling and was significantly higher in plants treated with low temperature. In most cases, the age of the transplants did not significantly affect enzyme activity, with the exception of the control treatment in 2008 and plants chilled for two

Table 2. Catalase $\left(\mu \mathrm{mol}\left(\mathrm{H}_{2} \mathrm{O}_{2}\right) \mathrm{min}^{-1} 100 \mathrm{~g}^{-1}\right.$ f.w. $)$ activity in broccoli transplants and harvested plants

\begin{tabular}{|c|c|c|c|c|c|}
\hline \multirow{2}{*}{ Tissue type } & \multirow{2}{*}{ Year } & \multirow{2}{*}{$\begin{array}{l}\text { Transplants age } \\
\text { (week) }\end{array}$} & \multicolumn{3}{|c|}{ Period of transplant chilling (week) } \\
\hline & & & 0 & 1 & 2 \\
\hline \multirow{6}{*}{ Transplants } & \multirow{2}{*}{2008} & 4 & $362.0 \mathrm{a}^{*}$ & $452.4 \mathrm{~b}$ & $758.5 \mathrm{c}$ \\
\hline & & 8 & $434.4 \mathrm{~b}$ & $496.5 \mathrm{~b}$ & $765.3 \mathrm{c}$ \\
\hline & \multirow{2}{*}{2009} & 4 & $376.0 \mathrm{a}$ & $607.0 \mathrm{bc}$ & $551.7 \mathrm{~b}$ \\
\hline & & 8 & $334.3 \mathrm{a}$ & $662.0 \mathrm{c}$ & $772.0 \mathrm{~d}$ \\
\hline & \multirow{2}{*}{2010} & 4 & 296.9 a & $731.9 \mathrm{bc}$ & $980.2 \mathrm{~d}$ \\
\hline & & 8 & $456.8 \mathrm{a}$ & $656.9 \mathrm{~b}$ & $786.2 \mathrm{c}$ \\
\hline \multirow{6}{*}{ Leaves } & \multirow{2}{*}{2008} & 4 & $1123.5 \mathrm{a}$ & $1078.2 \mathrm{a}$ & $1173.3 \mathrm{a}$ \\
\hline & & 8 & $1129.5 \mathrm{a}$ & $1142.5 \mathrm{a}$ & $1121.7 \mathrm{a}$ \\
\hline & \multirow{2}{*}{2009} & 4 & $1167.8 \mathrm{a}$ & $1358.7 \mathrm{~b}$ & $1202.7 \mathrm{ab}$ \\
\hline & & 8 & $1246.0 \mathrm{ab}$ & $1166.7 \mathrm{a}$ & $1186.2 \mathrm{ab}$ \\
\hline & \multirow{2}{*}{2010} & 4 & $1103.0 \mathrm{~b}$ & $839.2 \mathrm{a}$ & $730.6 \mathrm{a}$ \\
\hline & & 8 & $1095.3 \mathrm{~b}$ & $909.1 \mathrm{ab}$ & $697.0 \mathrm{a}$ \\
\hline \multirow{6}{*}{ Heads } & \multirow{2}{*}{2008} & 4 & $237.9 \mathrm{~cd}$ & $190.2 \mathrm{ab}$ & $183.9 \mathrm{a}$ \\
\hline & & 8 & $219.0 \mathrm{bc}$ & $266.1 \mathrm{~d}$ & $337.3 \mathrm{e}$ \\
\hline & \multirow{2}{*}{2009} & 4 & $126.9 \mathrm{a}$ & $147.1 \mathrm{ab}$ & $154.5 \mathrm{~b}$ \\
\hline & & 8 & $183.7 \mathrm{c}$ & $132.9 \mathrm{ab}$ & $132.4 \mathrm{ab}$ \\
\hline & \multirow{2}{*}{2010} & 4 & $92.6 \mathrm{~cd}$ & 81.7 bc & $71.4 \mathrm{~b}$ \\
\hline & & 8 & $100.9 \mathrm{~d}$ & $97.2 \mathrm{~cd}$ & $52.0 \mathrm{a}$ \\
\hline
\end{tabular}

*Means followed by the same letters are not significantly different at $\mathrm{p}=0.05$ 


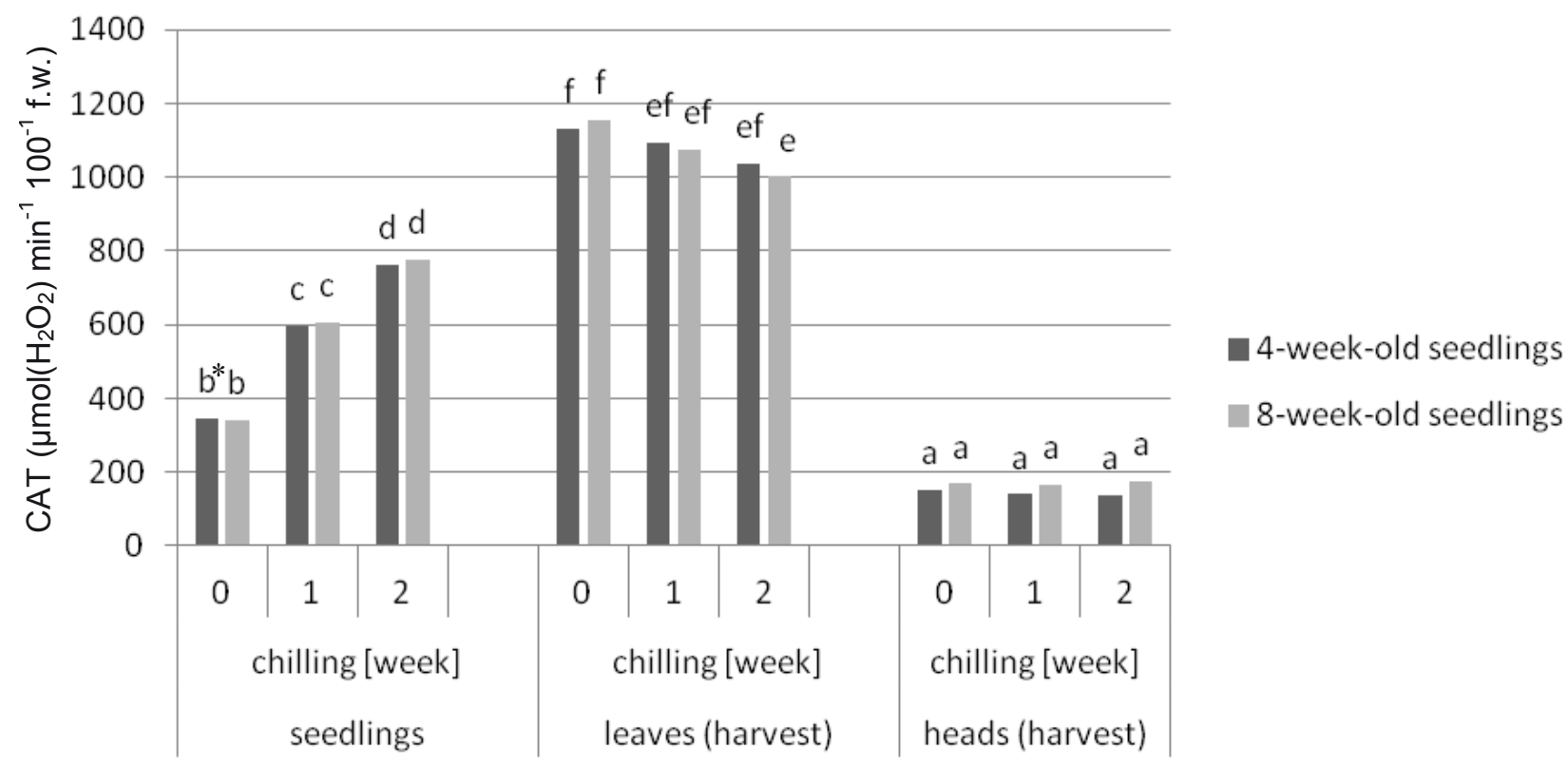

*Means followed by the same letters are not significantly different at $\mathrm{p}=0.05$

Figure 1. Catalase activity in broccoli transplants and at harvest time: in leaves and heads. Mean values from the years 2008-2010

weeks in 2010, where CAT activity was about $20 \%$ higher in younger transplants. The opposite effect was observed in 2009 for plants treated with low temperature for two weeks (Tab. 2).

The activity of CAT determined in broccoli leaves distinctly increased during plant development (Tab. 2). There were no significant differences in CAT activity in broccoli leaves obtained from previously chilled plants at harvest time in 2008 and 2009; in 2010, the enzyme activity determined in the leaves of plants treated with low temperature at the transplant stage was 35\% lower in comparison with the control group (Tab. 2).

CAT activity in broccoli heads was considerably lower (about 7 to $20 \%$ ) than in leaves and differed in each year (Tab. 2). In 2008 the enzyme activity

Table 3. Peroxidase (U $100^{-1}$ f.w.) activity in broccoli transplants and harvested plants

\begin{tabular}{|c|c|c|c|c|c|}
\hline \multirow{2}{*}{ Organ } & \multirow{2}{*}{ Year } & \multirow{2}{*}{$\begin{array}{c}\text { Transplant age } \\
\text { (week) }\end{array}$} & \multicolumn{3}{|c|}{ Period of transplant chilling (weeks) } \\
\hline & & & 0 & 1 & 2 \\
\hline \multirow{6}{*}{ Transplants } & \multirow{2}{*}{2008} & 4 & $551.7 \mathrm{a}^{*}$ & $700.0 \mathrm{~b}$ & $956.0 \mathrm{c}$ \\
\hline & & 8 & $753.0 \mathrm{~b}$ & $876.0 \mathrm{c}$ & $1384.0 \mathrm{~d}$ \\
\hline & \multirow{2}{*}{2009} & 4 & $480.7 \mathrm{a}$ & $702.0 \mathrm{~b}$ & $752.7 \mathrm{~b}$ \\
\hline & & 8 & $944.0 \mathrm{c}$ & $1246.3 \mathrm{~d}$ & $1561.3 \mathrm{e}$ \\
\hline & \multirow{2}{*}{2010} & 4 & $308.7 \mathrm{a}$ & $291.3 \mathrm{a}$ & $395.6 \mathrm{~b}$ \\
\hline & & 8 & $513.3 \mathrm{c}$ & $381.0 \mathrm{~b}$ & $504.0 \mathrm{c}$ \\
\hline \multirow{6}{*}{ Leaves } & \multirow{2}{*}{2008} & 4 & $1365.0 \mathrm{bc}$ & $3088.0 \mathrm{e}$ & $2730.7 \mathrm{~d}$ \\
\hline & & 8 & $942.3 \mathrm{a}$ & $1449.0 \mathrm{c}$ & $1164.7 \mathrm{ab}$ \\
\hline & \multirow{2}{*}{2009} & 4 & $1987.3 \mathrm{a}$ & $3094.0 \mathrm{c}$ & $2867.7 \mathrm{bc}$ \\
\hline & & 8 & 2085.7 a & $2850.3 \mathrm{~b}$ & $2213.3 \mathrm{a}$ \\
\hline & \multirow{2}{*}{2010} & 4 & $3396.0 \mathrm{~d}$ & $2625.0 \mathrm{~b}$ & $3363.0 \mathrm{~d}$ \\
\hline & & 8 & $2835.0 \mathrm{bc}$ & $3027.0 \mathrm{c}$ & $2148.0 \mathrm{a}$ \\
\hline \multirow{6}{*}{ Heads } & \multirow{2}{*}{2008} & 4 & $1895.3 \mathrm{~b}$ & $3845.3 \mathrm{~d}$ & $3328.0 \mathrm{c}$ \\
\hline & & 8 & $1450.7 \mathrm{a}$ & $1521.7 \mathrm{a}$ & $1429.3 \mathrm{a}$ \\
\hline & \multirow{2}{*}{2009} & 4 & $3637.3 \mathrm{ab}$ & $5120.0 \mathrm{bc}$ & $5920.0 \mathrm{c}$ \\
\hline & & 8 & $2417.7 \mathrm{a}$ & 2762.7 a & $3648.0 \mathrm{ab}$ \\
\hline & \multirow{2}{*}{2010} & 4 & $1999.2 \mathrm{a}$ & $2304.0 \mathrm{~b}$ & $3987.0 \mathrm{~d}$ \\
\hline & & 8 & $2200.8 \mathrm{ab}$ & $2028.0 \mathrm{a}$ & $3165.0 \mathrm{c}$ \\
\hline
\end{tabular}

*Means followed by the same letters are not significantly different at $\mathrm{p}=0.05$ 


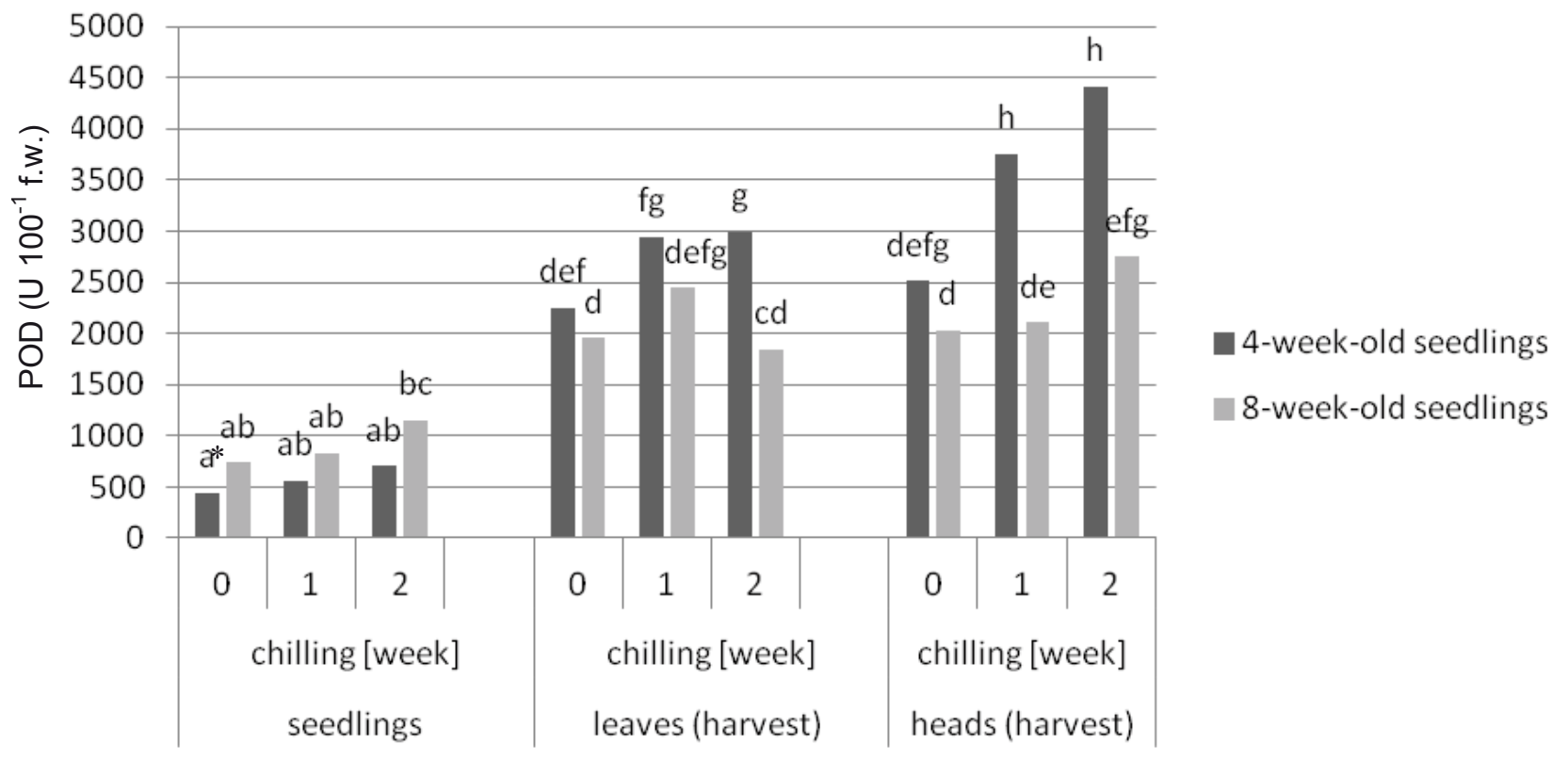

*Means followed by the same letters are not significantly different at $\mathrm{p}=0.05$

Figure 2. Peroxidase activity in broccoli transplants and at harvest time: in leaves and heads. Mean values from the years 2008-2010

in broccoli heads obtained from eight-week-old transplants was stimulated by chilling, while in the case of younger plants, a decrease of about $20 \%$ was observed. In the next year, the situation was reversed and CAT activity, in general, was about $50 \%$ lower than in the previous year. In 2010, the chilling of transplants resulted in a decrease of CAT activity, irrespective of their age. The average values of CAT activity showed no significant differences between plants grown from four-week-old and eight-weekold transplants (Fig. 1).

The stimulatory effect of transplant chilling on the activity of this enzyme was revealed only directly after the removal plants from the cold chamber. During harvest time, CAT activity was significantly higher in the leaves than in the heads.

\section{Peroxidase (POD)}

Low temperature treatment of transplants caused a significant increase of POD activity in the transplants, leaves and heads in 2008 and in 2009. In 2010, the effect of chilling was not evident. In each experimental season, POD activity in the eight-week-old transplants exceeded that of the four-week-old ones by about 20 to $50 \%$. Similarly as in the case of CAT, POD activity distinctly rose during plant growing (Tab. 3).

At harvest time, the stimulation of POD activity by the chilling of transplants was found both in the leaves and in the heads, particularly in plants obtained from the four-week-old transplants, where $30-50 \%$ POD activity increase was observed. In most cases, the POD activity measured in broccoli heads was about $20-45 \%$ higher than that of the leaves. Both of the chilling periods stimulated POD activity in comparison to the control group (Fig. 2).

\section{Phenolic substances}

The chilling of broccoli transplants caused an accumulation of phenolics (total, cinnamic acid derivatives and flavonols) in 2008. The same effect was observed in 2009 in the case of eight-week-old transplants. In the last experimental season (2010), the level of phenolics determined in the transplants kept at a low temperature was similar to the control samples (Tab. 4).

In general, the phenolic compounds detected in the broccoli leaves and heads at harvest time were not influenced by the preliminary chilling of transplants. Differences were observed in individual years: in 2008, the level of phenolic constituents was $15-20 \%$ higher in the leaves of broccoli planted as eight-week-old transplants in comparison to the younger plants, while in the case of the heads the opposite effect was found. In 2008, the content of phenolic substances in the leaves was poor (about $79 \%$ lower) as related to the following years and significantly lower than in the heads. The differences between leaves and heads were not evident in 2009 and 2010 (Tab. 5). 
Table 4. Phenolic compounds (mg $100 \mathrm{~g}^{-1}$ f.w.) in broccoli transplants before and after chilling

\begin{tabular}{|c|c|c|c|c|c|}
\hline \multirow{2}{*}{ Compounds } & \multirow{2}{*}{ Year } & \multirow{2}{*}{$\begin{array}{l}\text { Transplant age } \\
\text { (week) }\end{array}$} & \multicolumn{3}{|c|}{ Period of transplant chilling (weeks) } \\
\hline & & & 0 & 1 & 2 \\
\hline \multirow{6}{*}{ Total phenols } & \multirow{2}{*}{2008} & 4 & $188.43 \mathrm{a}^{*}$ & $306.87 \mathrm{c}$ & $337.70 \mathrm{~d}$ \\
\hline & & 8 & $248.27 b$ & $315.97 \mathrm{~cd}$ & $304.23 \mathrm{c}$ \\
\hline & \multirow{2}{*}{2009} & 4 & $196.16 \mathrm{~b}$ & $167.68 \mathrm{a}$ & $187.27 \mathrm{~b}$ \\
\hline & & 8 & $159.70 \mathrm{a}$ & $197.27 \mathrm{~b}$ & $254.85 \mathrm{c}$ \\
\hline & \multirow{2}{*}{2010} & 4 & $185.35 \mathrm{ab}$ & $175.25 \mathrm{a}$ & $206.87 \mathrm{bc}$ \\
\hline & & 8 & $261.82 \mathrm{~d}$ & $211.92 \mathrm{bc}$ & $216.67 \mathrm{c}$ \\
\hline \multirow{6}{*}{$\begin{array}{l}\text { Cinnamic acid } \\
\text { derivatives }\end{array}$} & \multirow{2}{*}{2008} & 4 & 72.83 a & $126.20 \mathrm{~cd}$ & $136.40 \mathrm{~d}$ \\
\hline & & 8 & $96.90 \mathrm{~b}$ & $127.30 \mathrm{~cd}$ & $116.30 \mathrm{c}$ \\
\hline & \multirow{2}{*}{2009} & 4 & $81.59 \mathrm{bc}$ & $66.35 \mathrm{a}$ & $74.41 \mathrm{ab}$ \\
\hline & & 8 & $67.70 \mathrm{a}$ & $72.54 \mathrm{ab}$ & $90.22 \mathrm{c}$ \\
\hline & \multirow{2}{*}{2010} & 4 & $75.13 \mathrm{a}$ & $71.4 \mathrm{a}$ & $76.84 \mathrm{a}$ \\
\hline & & 8 & $101.23 \mathrm{~b}$ & $79.16 \mathrm{a}$ & $79.28 \mathrm{a}$ \\
\hline \multirow{6}{*}{ Flavonols } & \multirow{2}{*}{2008} & 4 & 72.63 a & $133.97 \mathrm{c}$ & $147.30 \mathrm{~d}$ \\
\hline & & 8 & $103.67 \mathrm{~b}$ & $140.40 \mathrm{~cd}$ & $128.80 \mathrm{c}$ \\
\hline & \multirow{2}{*}{2009} & 4 & $84.16 \mathrm{~d}$ & $66.80 \mathrm{~b}$ & $76.49 \mathrm{c}$ \\
\hline & & 8 & $59.10 \mathrm{a}$ & $74.54 \mathrm{c}$ & $93.98 \mathrm{e}$ \\
\hline & \multirow{2}{*}{2010} & 4 & $75.43 \mathrm{a}$ & $73.45 \mathrm{a}$ & $79.64 \mathrm{a}$ \\
\hline & & 8 & $109.68 \mathrm{~b}$ & $83.07 \mathrm{a}$ & $83.74 a$ \\
\hline
\end{tabular}

* Means followed by the same letters are not significantly different at $\mathrm{p}=0.05$

Table 5. Phenolic compounds (mg $100 \mathrm{~g}^{-1}$ f.w.) in broccoli leaves and heads at harvest time

\begin{tabular}{|c|c|c|c|c|c|c|c|c|}
\hline \multirow{3}{*}{ Compounds } & \multirow{3}{*}{ Year } & \multirow{3}{*}{$\begin{array}{c}\text { Transplant } \\
\text { age (weeks) }\end{array}$} & \multicolumn{3}{|c|}{ Leaves } & \multicolumn{3}{|c|}{ Heads } \\
\hline & & & \multicolumn{3}{|c|}{ period of transplant chilling (weeks) } & \multicolumn{3}{|c|}{ period of transplant chilling (weeks) } \\
\hline & & & 0 & 1 & 2 & 0 & 1 & 2 \\
\hline \multirow{6}{*}{ Total phenols } & \multirow{2}{*}{2008} & 4 & $70.90 \mathrm{a}^{*}$ & $76.37 \mathrm{ab}$ & $74.83 \mathrm{ab}$ & $202.43 \mathrm{bc}$ & $222.90 \mathrm{~d}$ & $219.60 \mathrm{~cd}$ \\
\hline & & 8 & $83.53 \mathrm{bc}$ & $94.73 \mathrm{c}$ & $89.20 \mathrm{c}$ & $171.03 \mathrm{a}$ & $167.23 \mathrm{a}$ & $184.63 \mathrm{ab}$ \\
\hline & \multirow{2}{*}{2009} & 4 & $255.56 \mathrm{a}$ & $304.44 \mathrm{~b}$ & $243.94 \mathrm{a}$ & $104.85 \mathrm{a}$ & $133.84 \mathrm{c}$ & $144.14 \mathrm{~d}$ \\
\hline & & 8 & $245.66 \mathrm{a}$ & $256.77 \mathrm{a}$ & $250.20 \mathrm{a}$ & $113.33 \mathrm{ab}$ & $109.29 \mathrm{ab}$ & $115.96 \mathrm{~b}$ \\
\hline & \multirow{2}{*}{2010} & 4 & $213.03 \mathrm{c}$ & $188.18 \mathrm{ab}$ & $217.88 \mathrm{c}$ & $117.78 \mathrm{c}$ & $101.72 \mathrm{a}$ & $154.95 \mathrm{~b}$ \\
\hline & & 8 & $198.18 \mathrm{abc}$ & $174.65 \mathrm{a}$ & $200.61 \mathrm{bc}$ & $151.11 \mathrm{~b}$ & $110.81 \mathrm{ab}$ & $107.47 \mathrm{ab}$ \\
\hline \multirow{6}{*}{$\begin{array}{l}\text { Cinnamic acid } \\
\text { derivatives }\end{array}$} & \multirow{2}{*}{2008} & 4 & $14.70 \mathrm{a}$ & $17.17 \mathrm{ab}$ & $16.87 \mathrm{ab}$ & $68.07 \mathrm{~cd}$ & $66.00 \mathrm{~cd}$ & $71.57 \mathrm{~d}$ \\
\hline & & 8 & $19.93 \mathrm{~b}$ & $29.33 \mathrm{c}$ & $26.97 \mathrm{c}$ & $55.45 \mathrm{ab}$ & $52.60 \mathrm{a}$ & $61.87 \mathrm{bc}$ \\
\hline & \multirow{2}{*}{2009} & 4 & $85.29 \mathrm{~b}$ & $101.59 \mathrm{c}$ & $80.57 \mathrm{ab}$ & $22.28 \mathrm{~b}$ & $26.19 \mathrm{~d}$ & $25.40 \mathrm{~cd}$ \\
\hline & & 8 & $78.86 \mathrm{a}$ & $84.54 \mathrm{ab}$ & $81.71 \mathrm{ab}$ & $23.87 \mathrm{bc}$ & $19.60 \mathrm{a}$ & $25.34 \mathrm{~cd}$ \\
\hline & \multirow{2}{*}{2010} & 4 & $63.01 \mathrm{c}$ & $57.42 \mathrm{ab}$ & $71.85 \mathrm{~d}$ & $22.38 \mathrm{ab}$ & $18.67 \mathrm{a}$ & $26.46 \mathrm{~cd}$ \\
\hline & & 8 & $58.68 \mathrm{bc}$ & $53.24 \mathrm{a}$ & $63.19 \mathrm{c}$ & $29.88 \mathrm{~d}$ & $23.81 \mathrm{bc}$ & $19.27 \mathrm{a}$ \\
\hline \multirow{6}{*}{ Flavonols } & \multirow{2}{*}{2008} & 4 & $12.77 \mathrm{a}$ & $14.77 \mathrm{a}$ & $15.30 \mathrm{a}$ & $74.87 \mathrm{~cd}$ & $71.07 \mathrm{c}$ & $80.73 \mathrm{~d}$ \\
\hline & & 8 & $16.33 \mathrm{a}$ & $28.47 \mathrm{~b}$ & $26.27 \mathrm{~b}$ & $62.27 \mathrm{ab}$ & $58.90 \mathrm{a}$ & $68.50 \mathrm{bc}$ \\
\hline & \multirow{2}{*}{2009} & 4 & $94.76 \mathrm{~b}$ & $111.92 \mathrm{c}$ & $88.94 \mathrm{ab}$ & $19.49 \mathrm{~b}$ & $23.18 \mathrm{~d}$ & $22.30 \mathrm{~cd}$ \\
\hline & & 8 & $86.60 \mathrm{a}$ & $93.72 \mathrm{~b}$ & $92.01 \mathrm{ab}$ & $20.90 \mathrm{bc}$ & $16.43 \mathrm{a}$ & $21.62 \mathrm{~cd}$ \\
\hline & \multirow{2}{*}{2010} & 4 & $65.13 \mathrm{~b}$ & $63.73 \mathrm{~b}$ & $78.91 \mathrm{~d}$ & $19.91 \mathrm{~b}$ & $15.39 \mathrm{a}$ & $28.23 \mathrm{c}$ \\
\hline & & 8 & $60.87 \mathrm{ab}$ & $58.17 \mathrm{a}$ & $72.15 \mathrm{c}$ & $26.93 \mathrm{c}$ & $20.48 \mathrm{~b}$ & $14.92 \mathrm{a}$ \\
\hline
\end{tabular}

*Means followed by the same letters are not significantly different at $p=0.05$ 


\section{DISCUSSION}

One of the first plant cell responses to stress is the formation of large quantities of hydrogen peroxide, as an important activator of signal transmission. At the same time, this very reactive molecule is dangerous for structural and functional cell elements when uncontrollably produced (Ślesak et al. 2007). Studies have shown that the excessive formation of hydrogen peroxide is connected with the exposition of plant to stress conditions, including low temperatures, and causes an increase of CAT and POD activity, which are responsible for its scavenging (Feierabend 2005, Bartosz 2006, Ślesak et al. 2007).

CAT can be found mainly in peroxisomes, particularly in assimilation cells (Bartosz 1997, Feierabend 2005). In our study, CAT activity was significantly higher in broccoli leaves than in the heads. In the present investigation, the increase of CAT activity after one- and two-week transplant chilling periods was observed only in broccoli transplants immediately after removal from the cold chamber and the effect was not noticed in the adult plants. Similar results concerning CAT activity in leaves' mitochondria were observed by Prasad et al. (1994) in the case of chilling corn seedlings.

At the time of harvest, there was no effect of transplant chilling on the activity of this enzyme in the heads and CAT activity decreased in the leaves in the case of the chilling treatment. This suggests that increased CAT activity may be a relatively quick response to stress conditions and is not maintained in subsequent stages of development. There were no significant differences between CAT activity in plants grown from four- or eight-weekold transplants.

The other enzyme responsible for hydrogen peroxide scavenging is peroxidase, whose high activity is found in Brassicaceae plants. POD activity measured in broccoli heads has been

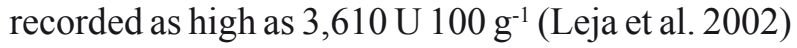
and has even reached 4,200 U $100 \mathrm{~g}^{-1}$ (Starzyńska et al. 2003). Our data show similar mean values of POD activity in broccoli heads harvested from plants grown from four-week-old transplants.

The influence of chilling on young transplants immediately removed from the cold chamber was not evident, but in adult leaves of broccoli grown from four-week-old transplants, POD activity was higher in combinations with chilling. This may suggest the long-term reaction of this enzyme's activity caused by low temperature stress. An increase of POD activity in leaves was also observed in the case of chilled corn plants (Prasad et al. 1994, Fryer et al. 1998). In particular, POD activity in corn leaf mitochondria was much higher when previously subjected to seven days of acclimatisation at low temperatures (Prasad et al. 1994). Higher POD activity in broccoli heads grown from chilled transplants may suggest that the acclimatisation of this plant in the early stage of development can affect the expression of this enzyme in the entire organism, including organs produced at later developmental stages. Plants obtained from the younger transplants (four weeks old) previously treated with low temperature were characterised by more intensive POD activity. This may imply a better physiological response and greater adaptability of broccoli to adverse environmental conditions in the crop of young transplants.

Comparing the reactions of the two studied enzymes to the experimental factors showed no direct correlation between the functioning of CAT and POD in broccoli tissues. Catalase exhibited a significantly higher activity in assimilation tissues compared to samples taken from the heads; however, high peroxidase activity was noticed in both the leaves and heads of the examined broccoli during harvest. Feierabend (2005) gives a possible explanation of this situation, suggesting that CAT has a relatively low affinity to hydrogen peroxide, making it effective in its removal only with high concentrations of $\mathrm{H}_{2} \mathrm{O}_{2}$, which are especially found in photosynthetically active cells. Conversely, POD shows a very high affinity to this molecule, making it already effective at low concentrations of hydrogen peroxide (provided an appropriate, reduced reaction substrate), which can occur in various plant tissues, including the generative organs (Mittler and Poulos 2005).

Phenolics are an important group of compounds with antioxidant properties, commonly occurring in the plant kingdom. One of the most strongly represented groups of phenols are cinnamic acid derivatives. Their high antioxidant activity is associated with the number of hydroxyl groups in the molecule (Grajek 2007). Phenolic compounds are synthesised during the development of heads (Leja et al. 2002) and are also accumulated as a result of post-harvest treatment (Leja et al. 2001, Starzyńska et al. 2003) and can be stimulated by some growing conditions, such as reduced nitrogen form (Leja et al. 1997). In the present experiment, the content of phenolic compounds (total, cinnamic acid derivatives and flavonols) in both broccoli leaves and heads varied in each year. A reaction to 
low temperature treatment was only visible in the transplants, while no evident effect of preliminary chilling on the content of those constituents in leaves and flower buds was observed.

This variability observed between individual years might have been due to climatic conditions, particularly the various levels of rainfall noted at the moment of planting (June); the younger (fourweek-old) transplants were more sensitive to drought stress. The synthesis and accumulation of phenolic compounds is one of the most common defence system of plants against biotic and abiotic stress (Bartosz 2006).

In general, the results obtained in the present study confirm plant response to low temperature stress as expressed by some antioxidative parameters. Both CAT activity and the content of phenolic constituents increased after the chilling of young plants but were not maintained during further broccoli development. In the case of peroxidase, the reaction to previous low temperature treatments occurred in the fully mature plants and was observed not only in assimilate (leaves) tissue but also in the edible parts (heads). The differences in plant defence mechanisms between the two enzymes responsible for $\mathrm{H}_{2} \mathrm{O}_{2}$ decomposition are important, first of all, from a theoretical point of view, but did not affect either plant development or crop quality.

The preliminary chilling (one or two weeks) of broccoli transplants might have been treated as their acclimatisation to allow for the adaptation of the plants to environmental conditions and for the shortening of their growing period in the field without any negative effects on the biological quality of the crop.

\section{CONCLUSIONS}

1. Low temperature treatment increased catalase activity in broccoli transplants.

2. The preliminary chilling of broccoli plants induced peroxidase activity in leaves and heads determined at harvest time.

3. The effect of preliminary chilling of plants on the synthesis of phenolic substances at harvesting was not evident.

\section{ACKNOWLEDGEMENTS}

This study was supported by the Ministry of Science and Higher Education in Poland. Project No N N310 309434.

\section{REFERENCES}

Bartosz G., 1997. Oxidative stress in plants. Acta Physiol. Plant. 19: 47-64.

Bartosz G., 2006. Another side of oxygen. Free radicals in nature. Wydawnictwo Naukowe PWN, Warsaw (In Polish)

Borowski J., Szajdek A., Borowska E.J., Ciska E., ZiELINSKi H., 2008. Content of selected bioactive components and antioxidant properties of broccoli (Brassica oleracea L.). Eur. Food Res. Technol. 226: 459-465.

Feierabend J. 2005. Catalases in plants: molecular and functional properties and role in stress defense. In: Antioxidants and reactive oxygen species in plants. N. Smirnoff (ed.), Blackwell Publishing Ltd.

Fryer M.J., Andrews J.R., Oxborough K., Blowers D.A., BAKER N.R., 1998. Relationships between $\mathrm{CO}_{2}$ assimilation, photosynthetic electron transport and active $\mathrm{O}_{2}$ metabolism in leaves of maize in the field during periods of low temperature. Plant Physiol. 116: $571-580$.

Fukumoto L., Mazza G., 2000. Assessing antioxidant and prooxidant activities of phenolic compounds. J. Agric. Food Chem. 48/8: 3597-3604.

Grace S.C., 2005. Phenolics as antioxidants. In: Antioxidants and reactive oxygen species in plants. N. Smirnoff (ed.), Blackwell Publishing Ltd.

GrajeK W., 2007. Antioxidants in food. Health, technological, molecular and analytical aspects. Wydawnictwa Naukowo-Techniczne, Warsaw (In Polish).

Jefreey E.H., Araya M., 2009. Physiological effects of broccoli consumption. Phytochem. Rev. 8: 283-298.

Kunicki E., 1998. Broccoli growing. Hortpress, Warsaw (In Polish).

Leja M., Mareczek A., Starzyńska A., Rożek S., 2001. Antioxidant ability of broccoli flower buds during short-term storage. Food Chem. 72(2): 219-222.

Leja M., Mareczek A., Starzyńska A., 2002. Some antioxidant and senescence parameters of broccoli as related to its developmental stages. Acta Physiol. Plant. 24: 237-241.

Leja M., Wojciechowska R., Mareczek A., Kunicki E., 1997. The effect of fertilization with different forms of nitrogen on certain senescence indices in shortterm stored broccoli heads. Folia Hort. 9(1): 85-96.

LüCK H., 1962. Methoden der enzymatischen Analyse, Weinheim; Verlag Chemie GmbH.

Mittler R., Poulos T.L., 2005. Ascorbate peroxidase In: Antioxidants and reactive oxygen species in plants. N. Smirnoff. (ed.), Blackwell Publishing Ltd.

PodsęDEK A., 2007. Natural antioxidants and antioxidant capacity of Brassica vegetables: A review. LWT Food Sci. and Technol. 40: 1-11.

Prasad T.K., Anderson M.D., Martin B.A., Stewart C.R., 1994. Evidence for chilling-induced oxidative stress in maize seedlings and regulatory role of hydrogen peroxide. Plant Cell 6: 65-74. 
Sharma P., Jha A.B., Dubey R.S., 2011. Oxidative stress and antioxidative defense systems in plants growing under abiotic stress In: Handbook of Plant and Crop Stress. M. Pessarakli (ed.), CRC Press.

SHIRLEY B.W., 1996. Flavonoid biosynthesis: "new" functions for an "old" pathway. Trends Plant Sci. 1: 377-382.

Singh B.K., Sharma S.R., Singh B., 2010. Antioxidants enzymes in cabbage: Variability and inheritance of superoxide dismutase, peroxidase and catalase. Scientia Hort. 124: 9-13.

StarzyŃSKa A., LeJA M., MareczeK A., 2003. Physiological changes in the antioxidant system of broccoli flower buds senescing during short-term storage, related to temperature and packaging. Plant Sci. 165: 1387-1395.

Ślesak I., LibiK M., KarpińSKa B., KarpińSKi S., MisZALSKI Z., 2007. The role of hydrogen peroxide in regulation of plant metabolism and cellular signaling in response to environmental stress. Acta Biochim. Pol. 54(1): 39-50.

\section{WPŁYW WSTĘPNEGO CHŁODZENIA ROZSADY BROKUŁU NA WYBRANE PARAMETRY ANTYOKSYDACYJNE}

Streszczenie: Prezentowana praca, realizowana w latach 2008-2010 stanowi część projektu "Wpływ chłodzenia rozsady w różnym wieku na wysokość i jakość plonu brokułu (Brassica oleracea var. italica)". Celem projektu było skrócenie cyklu uprawowego brokułu poprzez optymalizację wieku wysadzanej na miejsce stałe rozsady jednocześnie uzyskując wysoką wartość biologiczną plonu. Przechowanie 4- i 8-tygodniowej rozsady w chłodni przed wysadzeniem na miejsce stałe skraca cykl wegetacyjny, jednocześnie jednak może wpłynąć na skład chemiczny liści i róż. Wcześniejsze badania wykazały, że chłodzenie rozsady wpływa na zwiększenie plonu brokułu, jakkolwiek potrzebna była również ocena jakości otrzymanego plonu z uwzględnieniem właściwości prozdrowotnych tego warzywa.

W niniejszym doświadczeniu 4- i 8-tygodniowa rozsada została przetrzymana $\mathrm{w}$ temperaturze $2^{\circ} \mathrm{C}$ przez okres 1 lub 2 tygodni przed wysadzeniem na miejsce stałe. Aktywność katalazy (CAT) i peroksydazy (POD) oraz akumulacja związków fenolowych oznaczone zostały w liściach rozsady przed chłodzeniem i tuż po wyjęciu w chłodni. Te same parametry zbadano $\mathrm{w}$ liściach i różach brokułów w terminie zbioru. Wpływ wstępnego chłodzenia na CAT stwierdzono jedynie $\mathrm{w}$ fazie rozsady, natomiast zwiększenie aktywności POD spowodowane zastosowanym chłodzeniem utrzymało się $w$ dalszych etapach wegetacji brokułu. Reakcja roślin na niską temperaturę może być związana z ich mechanizmem obronnym przeciw warunkom stresowym i może być on różny w przypadku tych dwóch enzymów. Wpływ chłodzenia na akumulację związków fenolowych (sumy fenoli, pochodnych kwasu cynamonowego i flawonoli) zaobserwowano tylko w fazie rozsady.

Różnice w aktywności enzymów oraz zawartości związków fenolowych zaobserwowane pomiędzy poszczególnymi latami były prawdopodobnie spowodowane różnicami w przebiegu warunków pogodowych.

Received June 4, 2012; accepted November 17, 2012 